\title{
KORELASI POLA ASUH OTORITER TERHADAP HASIL BELAJAR PADA KELAS V SD 4 PIJI DAWE KUDUS
}

\author{
Fitri Handayani $^{1}$, Sekar Dwi Ardianti ${ }^{2}$, M. Syaffrudin Kuryanto ${ }^{3}$
}

Universitas Muria Kudus, Indonesia

Email: fh2372199@gmail.com

Info Artikel Abstract

Sejarah Artikel:

Diserahkan:

Direvisi:

Disetujui:

\section{Keywords:}

Pola asuh otoriter, Hasil belajar
This study aims to determine the relationship between authoritarian in developing with elementary school student learning outcomes. This research is a quantitative correlation study conducted at SD 4 Piji Dawe District, Kudus Regency. The research subjects were 5th grade students of SD 4 Piji. Data collection techniques used include questionnaires, direct observation, interviews, research documentation. Interviews were conducted with students and the main. In analyzing the data, a Likert scale model is used, namely the assessment using a scale of 1 to 4 . Respondents are expected to provide an opinion on each question item ranging from 'always' to 'never' by circling or cross-marking the answers to be selected by the respondent on the questionnaire sheet. The results showed that there was a significant correlation between authoritarian parenting and learning outcomes of SD 4 Piji Dawe Kudus with a score of $r$ table $(-0.792>0.433)$ with a significance value of 0.000 , which means less than $0.05(0.000<0,05)$. From these data it can be concluded that there is a significant correlation between authoritarian parenting and learning outcomes at SD 4 Piji Dawe Kudus.

\begin{abstract}
Abstrak
Penelitian ini bertujuan untuk mengetahui hubungan Pola Asuh Otoriter terhadap hasil Belajar Siswa Sekolah Dasar. Penelitian ini merupakan penelitian kuantitatif korelasi yang dilaksanakan di SD 4 Piji Kecamatan Dawe Kabupaten Kudus. Subyek penelitian yaitu siswa kelas 5 SD 4 Piji. Teknik pengumpulan data yang digunakan meliputi angket, observasi langsung, wawancara, dokumentasi penelitian. Wawancara dilaksanakan dengan siswa dan utama. Dalam menganalisis data digunakan model Skala Likert yakni penilaian menggunakan skala 1 sampai 4. Responden diharapkan memberikan pendapat setiap butir pertanyaan mulai dari 'selalu' sampai 'tidak pernah' dengan melingkari atau memberi tanda silang pada jawaban yang akan dipilih oleh responden pada lembar kuesioner. Hasil penelitian menunjukan bahwa terdapat korelasi yang signifikan antara pola asuh otoriter dalam mengembangkan hasil belajar SD 4 Piji Dawe Kudus dengan skor diperoleh skor $r$ tabel $(-0,792>$ 0,433 ) dengan nilai signifikasi sebesar 0,000 , yang berarti kurang dari 0,05 ( $0,000<0,05)$. Dari data tersebut bisa diambil kesimpulan bahwa terdapat korelasi yang signifikan antara pola asuh otoriter dan hasil belajar SD 4 Piji Dawe Kudus.
\end{abstract}




\section{PENDAHULUAN}

Keluarga sebagai kelompok masyarakat terkecil terbentuk oleh ikatan dua orang dewasa yang berlainan jenis kelamin, wanita dan pria serta anak-anak yang mereka lahirkan. Dalam kelompok ini, arus kehidupan dikemudikan oleh orang tua. Alam mempercayakan pertumbuhan serta perkembangan anak pada mereka. Fungsi keluarga yang utama ialah mendidik anak-anaknya Pola asuh orang tua sangat berperan penting dalam proses belajar anak. Pengasuhan memerlukan sejumlah kemampuan interpersonal dan mempunyai tuntutan emosional yang besar, namun sangat sedikit pendidikan formal mengenai tugas ini. Kebanyakan orang tua mempelajari praktik mengasuh dari orang tua mereka sendiri. Ada orang tua yang bersikap memberikan kebebasan kepada anak dengan alasan supaya anak bisa mengembangkan potensi dirinya. Ada pula orang tua yang memberi kebebasan kepada anak tapi tetap memberikan kontrol, dan ada pula orang tua yang bersikap melindungi anak secara berlebihan dengan memberikan perlindungan terhadap gangguan dan bahaya fisik maupun psikologis, sampai anak tidak mencapai kebebasan atau selalu tergantung pada orang tua, perilaku orang tua tersebut disebut dengan over protective, dengan alasan agar anak tidak mengalami celaka, dan karena anak belum bisa berfikir secara logis maka perlu ada perlindungan yang ekstra (Ika Widiasih, 2017).

Menurut Wydia (2016), bentuk pola asuh oleh orang tua ada tiga macam yaitu, pola asuh otoriter, demokratis, dan permisif. Dimana dari masing-masing pola pengasuhan tersebut mempunyai dampak yang berbeda-beda bagi perkembang anak itu sendiri. Dengan demikian sebagai orang tua harus dapat menerapkan pola pengasuhan yang tepat kepada anak-anaknya sehingga dapat membantu anak dalam proses pembelajaran sehingga akan meningkatkan hasil belajar anak di sekolahan.

Menurut Djamarah (2014) hasil belajar dapat diukur melalui tes yang sering dikenal dengan tes hasil belajar. Tes prestasi belajar berupa tes yang disusun secara terencana untuk mengungkap kemampuan maksimal subyek dalam menguasai bahan-bahan atau materi yang telah diajarkan. Dalam kegiatan pendidikan tes hasil belajar dapat berbentuk ulangan harian, tes formatif, tes sumatif dan tes diagnostik. Oleh karena itu hasil belajar merupakan salah satu tujuan yang akan dicapai dalam proses belajar mengajar dalam sebuah lembaga pendidikan.

Tridhonanto (2014:35) menjelaskan Pola asuh otoriter adalah "pola asuh orang tua yang lebih mengutamakan membentuk kepribadian anak dengan cara menetapkan standart mutlak harus dituruti, biasanya disertai dengan ancaman - ancaman". Pola asuh otoriter adalah pola asuh yang bersifat memaksa anak, agar anak mau menuruti perintah orang tua, dan perintah itu jika tidak di lakukan akan menimbulkan ancaman-ancaman yang digunakan untuk memaksa anak.

Pola asuh permisif adalah "Pola asuh orang tua pada anak dalam rangka membentuk kepribadian anak dengan cara memberikan pengawasan yang sangat longgar dan memberikan kesempatan pada anaknya untuk melakukan sesuatu tanpa pengawasan yang cukup darinya". Anak diberikan kepercayaan penuh melakukan apa yang dianggap baik dan melatih anak untuk dapat bertanggung jawab. Tridhonanto (2014:41).

Tridhonanto (2014:43) menjelaskan Pola asuh demokratis adalah pola asuh orang tua yang menerapkan perlakuan kepada anak dalam rangka membentuk kepribadian anak dengan cara memproritaskan kepentingan anak yang bersikap rasional atau pemikiran - pemikiran. Anak diberikan kebebasan memilih apa yang mereka mau tetapi masih dalam pengawasan dan kontrol oleh orang tua. Dalam penelitian ini peneliti bertujuan untuk mengetahui korelasi pola asuh orang tua otoriter terhadap hasil belajar ranah pengetahuan siswa kelas V di SD 4 Piji Dawe Kudus.

\section{METODE PENELITIAN}

Penelitian ini merupakan penelitian kuatitatif korelasi yang dilaksanakan di SD 4 Piji Kecamatan Dawe Kabupaten Kudus. Subyek penelitian yaitu siswa kelas V SD 4 Piji. Teknik pengumpulan data yang digunakan meliputi angket, observasi langsung, wawancara, dokumentasi. Wawancara dilaksanakan dengan siswa dan guru kelas. Dalam menganalisis data digunakan model Skala Likert yakni penilaian menggunakan skala 1 sampai 4. Responden diharapkan memberikan pendapat setiap butir pertanyaan mulai dari 'selalu' sampai 'tidak pernah' dengan mencentang atau memberi tanda silang pada jawaban yang akan dipilih oleh responden pada lembar kuesioner. Selanjutnya data diolah dengan menggunakan bantuan apliasi microsoft word dan SPSS 16 For windows. Hasil korelasi dalam uji ini dapat dilihat pada output ItemTotal Statistis pada kolom parson Correlation, nilai tersebut kemudian dibandingkan dengan nilai $r$ tabel pada taraf signifikasi 0,05 dengan uji 2 sisi dan jumlah responden sebanyak 21 , 
maka diperoleh $r$ tabel sebesar 0,433. Menurut Sugiyono (2013 : 179) bila korelasi tiap faktor tersebut positif dan $\geq 0,433$ maka faktor tersebut memiliki construct yang kuat dan memiliki validitas yang baik. Sebaliknya apabila korelasi tiap faktor tersebut $\leq 0,433$ maka butir instrumen itu tidak valid.

\section{HASIL DAN PEMBAHASAN}

Pada penelitian ini terdapat dua variabel yang digunakan, diantaranya yaitu: variabel bebas pola asuh otoriter (X1) serta variabel terikat hasil belajar (Y). Peneltian ini dilaksanakan pada kelas V SD 4 Piji Dawe, Kudus. Pada hasil penelitian dan pembahasan akan didiskripsikan dari data masing-masing variabel yang sudah diolah dilihat dari hasil validitas dan reliabilitas. Selain itu juga akan disajikan diagram batang korelasi dari variabel. Berikut diskripsi responden penelitian siswa kelas V SD 4.

\section{Uji Validitas}

Uji validitas dilakukan untuk mengukur sejauh mana instrumen itu dapat mengungkap dengan tepat dan benar mengenai gejala yang akan diukur baik. Pengujian validitas dalam penelitian ini menggunakan dua metode yaitu dengan rumus correl menggunakan microsoft excell lalu dilanjutkan menggunakan SPSS Versi 16.0. Penentuan vaiditas diperoleh dengan menggunakan uji parson Corelation. Adapun hasil uji validitas instrumen angket dapat dilihat pada tabel berikut.

Tabel 1. Hasil Uji Validitaas Instrumen Angket

\begin{tabular}{cccccc}
\hline $\begin{array}{c}\text { No } \\
\text { Pernyataan }\end{array}$ & Hasil r Hitung & No Pernyataan & Hasil r Hitung & No Pernyataan & Hasil r Hitung \\
\hline 1 & .851 & 6 & .647 & 11 & .739 \\
\hline 2 & .658 & 7 & .579 & 12 & .660 \\
\hline 3 & .508 & 8 & .502 & 13 & .617 \\
\hline 4 & .830 & 9 & .614 & 14 & .561 \\
\hline 5 & .587 & 10 & .631 & 15 & .838 \\
\hline
\end{tabular}

Sumber: Data peneliti (2021)

Berdasarkan hasil perhitungan uji validitas data menggunakan microsoft excell dan aplikasi spss diketahui bahwa keseluruhan pernyataan dinyatakan valid karena nilai $r$ hitung telah melebihi dari nilai $r$ tabel untuk 21 responden sebesar 0,433. Taraf signifikasi adalah 5\% atau 0,05. Dari 15 item pernyataan yang memperoleh nilai $r$ hitung paling tinggi adalah pernyataan nomor 1 yaitu sebesar 0.851 dan yang memperoleh nilai $r$ hitung terkecil adalah pernyataan nomor 8 yaitu sebesar 0.502

\section{Uji Reliabilitas}

Uji Reliabilitas yaitu menguji konsistensi data yang dikumpulkan untuk menunjukkan bahwa alat ukur yang digunakan dalam penelitian keperilakuan memiliki keandalan sebagai alat ukur. Untuk mengukur reliabilitas dalam penelitian ini, penelitian menggunakan koefisien alpha dari Cronbach. Suatu konstruk atau variabel dikatakan reliabel jika memberikan nilai Cronbach Alpha lebih besar dari 0,60. Dalam penelitian ini peneliti bertujuan untuk mengetahui korelasi pola asuh orang tua otoriter terhadap hasil belajar ranah pengetahuan siswa kelas V di SD 4 Piji Dawe Kudus. Adapun hasil uji reliabilitas dapat dilihat pada tabel berikut.

Tabel 2. Hasil Reliabilitas

\begin{tabular}{cc}
\hline Reliability Statistics & \\
\hline Cronbach's Alpha & N of Items \\
\hline .971 & 15 \\
\hline
\end{tabular}

Berdasarkan tabel hasil perhitungan uji reliabilitas menggunakan aplikasi SPSS memperoleh nilai Cronbach's Alpha sebesar .971 yang berarti interpretasi sangat kuat dinyatakan reliabel dan konsisten karena nilai Cronbach's Alpha lebih dari 0,70 (Ghozali, 2013). 


\section{Uji Korelasi}

Tabel 3. Hasil korelasi

\begin{tabular}{lll}
\hline & $\mathbf{X}_{\mathbf{1}}$ & $\mathbf{Y}$ \\
\hline $\mathbf{X}_{\mathbf{I}} \quad$ Pearson Correlation & 1 &,- 792 \\
Sig.(2-tailed) & & .000 \\
$\mathbf{N}$ & 21 & 21 \\
\hline $\mathbf{Y} \quad$ Pearson Correlation &,- 792 & 1 \\
Sig.(2-tailed) & .000 & 21 \\
$\mathbf{N}$ & 21 & 21 \\
\hline
\end{tabular}

Sumber: Data peneliti (2021)

Data variabel Pola Asuh Otoriter diperoleh melalui angket yang terdiri dari 15 item dengan jumlah responden 21 siswa. Ada 4 alternatif jawaban dimana skor tertinggi 4 dan skor terendah 1. Berdasarkan data variabel Pola Asuh Otoriter, diperoleh skor $\mathrm{r}$ tabel $(-0,792>$ $0,433)$ dengan nilai signifikasi sebesar 0,000 , yang berarti kurang dari $0,05(0,000<0,05)$. Berdasarkan hasil tersebut maka terdapat hubungan kuat antara variabel $\mathrm{X}$ dan variabel $\mathrm{Y}$, bentuk hubungan antara kedua variabel tersebut adalah hubungan negtif yang berarti semakin tinggi variabel $\mathrm{X}$ maka semakin rendah variabel $\mathrm{Y}$.

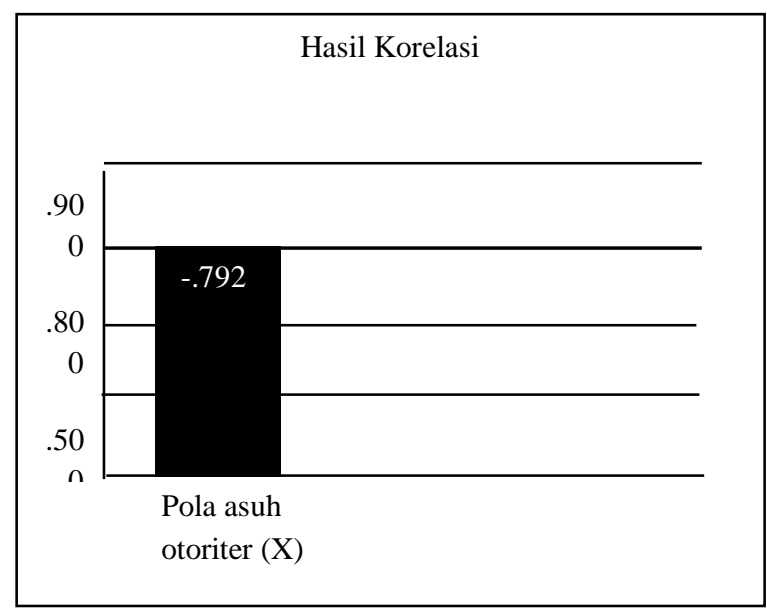

Gambar 4.1 Hasil Korelasi

Berdasarkan Gambar 4.1 Hasil perihtugan korelasi pola asuh otorier memperoleh skor -729 dan pola asuh demokratis memperoleh skor .856 dengan nilai signifikasi $0.000(0,000<0,05)$. Dari hasil ini skor yang diperoleh telah melebihi skor yang ditntukan untuk 21 responden yaitu 0, 344. Dari hasil tersebut dapat disimpulkan jika nilai thitung $\geq \mathrm{t}$-tabel pada $\alpha 0,05$ atau t-hitung $\mathrm{p}$ value $\leq 0,05$ maka Ho ditolak dan Ha diterima. Namun jika nilai t-hitung < t-tabel pada $\alpha 0,05$ atau t-hitung pada p-value > 0,05 maka Ho diterima dan Ha ditolak.

\section{Hubungan Antara Pola Asuh Ottoriter Dan Hasil Belajar Siswa SDN 4 Piji Dawe Kudus. \\ Berdasarkan hasil analisis data diketahui} bahwa terdapat korelasi yang signifikan antara pola asuh otoriter orang tua dalam mengembangkan hasil belajar siswa di SD 4 Piji Daawe Kudus. Hal ini ditunjukkan dari nilai $r$ hitung lebih besar dari $r$ tabel ($.792>0,433)$ dan nilai signifikasi lebih kecil dari $0,05 \quad(0,000<0,05)$. Artinya, apabila kecenderungan pola asuh otoriter semakin tinggi, maka akan semakin rendah hasil belajar siswa.

Hal ini senada dengan penelitian yang dilakukan Setiasih (2015: 5) yang berjudul "hubungan pola asuh orang tua dengan prestasi belajar siswa kelas $\mathrm{v}$ sd se-gugus wonokerto turi sleman" hasil penelitiannya menjelaskan terdapat hubungan yang positif dan signifikan antara pola asuh orang tua dengan prestasi belajar siswa kelas V SD Se-Gugus Wonokerto Turi Sleman tahun pelajaran 2014/2015, dengan diperoleh $\mathrm{R}=0,701$, Fhitung $=79,160$, dengan $\mathrm{p}=0,000$, Ftabel $=3,96$, dimana Fhitung $>$ Ftabel atau 79,160 > 3,96 dan nilai $\mathrm{p}<0,05$ atau $0,000<0,05$. Artinya semakin baik pola asuh orang tua terhadap siswa maka semakin tinggi prestasi belajar. Demikian juga sebaliknya semakin rendah pola asuh orang tua terhadap siswa maka semakin rendah prestasi belajar siswa.

Ditinjau dari hasil penelitian, diketahui bahwa korelasi pola asuh otoriter dalam mengembangkan hasil belajar memiliki hubungan yang kuat. Artinya semakin kuat sikap pola asuh otoriter yang di dapat anak, maka semakin menurun hasil belajar di sekolah. Hal ini dikarenakan anak merasa tertekan oleh pola asuh otoriter yang diterimanya, anak tidak memiliki kebebasan sehingga berpengaruh pada kognitifnya yang mengakibatkan hasil belajar menurun bila dibandingkan anak lain yang tidak mendapatkan pola asuh otoriter. Hal ini sejalan dengan pendapat Susanto (2013: 17) 
menyatakan bahwa keberhasilan siswa dalam belajar tergantung pada beberapa faktor salah satunya adalah faktor pola asuh. Pola asuh yang menyenangkan, tidak mengekang dan memaksakan kehenak anak tentunya berpengaruh terhadap keberhasilan belajar di sekolah.

Pola asuh otoriter adalah pola asuh yang bersifat memaksa anak, agar anak mau menuruti perintah orang tua, dan perintah itu jika tidak di lakukan akan menimbulkan ancaman-ancaman yang digunakan untuk memaksa anak. Ancaman itu agar anak mau tidak mau harus menuruti apa yang orang tua inginkan, tanpa adanya musyawarah antara orang tua dan anak. Hal ini menjadikan Orang tua murni sebagai rule model yang harus dituruti oleh anak. Dengan penerapan pola asuh semacam ini komunikasi atau hubungan antara orang tua dan anak cenderung menjadi renggang dan berdampak pada hasil belajar yang tidak maksimal (Tridhonanto 2014:35).

Pendapat ini diperkuat oleh penelitian yang dilakukan Karnangsyah dengan judul “ Hubungan Pola Asuh Orang Tua Dengan Hasil Belajar Siswa dan Implikasinya Terhadap Pelayanan Bimbingan dan Konseling" hasil penelitian tersebut menjelaskan bahwa Pola asuh orangtua memiliki pengaruh terhadap pencapaian hasil belajar siswa. Sikap dan perhatian orang tua, baik dari ayah atau ibu terhadap anaknya dalam melakukan aktivitas belajar, akan menimbulkan pengaruh positif terhadap hasil belajar yang dicapainya. Dari hasil paparan data pola asuh otorier dipengaruhi oleh beberapa faktor yaitu seperti faktor internal dan faktor exsternal. Contoh faktor internal yaitu kesehatan siswa terganggu atau kesehatan rohaninya kuarang baik. Misalnya mengalami perasaan kecewa karena sikap orang tua yang terlalu otoriter. Hal ini bisa mengganggu atau mengurangi semangat dan minat belajar sehingga membuat hasil belajar menurun. Oleh karena itu, pemeliharaan kesehatan sangat penting bagi setiap orang, baik fisik maupun mental, agar badan tetap kuat, pikiran selalu segar dan bersemangat dalam melaksanakan kegiatan belajar. Contoh faktor eksternal yaitu lingkungan rumah dimana pola asuh otoriter orang tua yang diterapkan ke anaknya berpengaruh besar terhadap hasil belajar di sekolah.

Lingkungan sekolah yang merupakan tempat terjadinya proses belajar mengajar antara siswa dan guru. Lingkungan sekolah yang berkualitas, dengan sarana dan prasarana yang memadai dapat menumbuhkan semangat dan hasil belajar yang lebih baik. Sementara itu
Wahayudi (2015: 578) dalam hasil penelitiannya menjelaskan bahwa pola asuh orang tua adalah salah satu faktor dan aspek penting yang dapat mendukung perilaku siswa untuk berprestasi. Pola asuh orang tua juga berpengaruh terhadap pengembangan intelektual siswa, termasuk pengembangan prestasi belajar.

Hasil penelitian senada dengan pendapat Slameto (2010: 54) yang mengatakan bahwa, "Faktor-faktor mempengaruhi belajar dapat dikategorikan menjadi dua yaitu faktor internal dan faktor eksternal." Faktor internal terbagi menjadi tiga yaitu faktor jasmaniah, faktor psikologi, dan faktor kelelahan. Faktor eksternal yang berpengaruh terhadap belajar, dapat dikelompokan menjadi tiga faktor, yaitu: faktor keluarga, faktor sekolah, dan masyarakat. Lebih lanjut Budiarnawan et al., (2014; 6) menjelaskan faktor yang mempengaruhi hasil belajar siswa adalah budaya keluarga. Dimana dalam pengasuhan anak, seorang anak akan memperoleh perkembangan yang sangat baik apabila pola asuh yang diterapkan oleh orang tuanya sesuai dengan kebutuhan dan kondisi dari setiap individu anak. Soraya, (2015: 8) menambahkan orang tua harus lebih teliti dalam menyikapi perannya kepada anak dan harus menerapkan pola asuh yang baik dalam mengasuh anaknya karena seorang anak adalah aset dalam keluarga yang harus dijaga, dibimbing dan diarahkan agar kelak menjadi anak yang memiliki kepribadian luhur dan perkembangan intelektual yang tinggi.

\section{KESIMPULAN}

Berdasarkan hasil analisis dan pembahasan tentang dapat ditarik kesimpulan dari analisis data bahwa, terdapat korelasi yang signifikan antara pola asuh otoriter dan hasil belajar SD 4 Piji Dawe Kudus. Berdasarkan hasil analisis data diketahui bahwa terdapat korelasi yang signifikan antara pola asuh otoriter dan hasil belajar SD 4 Piji Dawe Kudus. Hal ini ditunjukkan dari nilai $r$ hitung lebih besar dari $r$ tabel $(-.792>0,433)$ dan nilai signifikasi lebih kecil dari $0,05(0,00<0,05)$. Berdasarkan hasil tersebut maka terdapat hubungan kuat antara variabel $\mathrm{X}$ dan variabel $\mathrm{Y}$, bentuk hubungan antara kedua variabel tersebut adalah hubungan negatif yang berarti semakin tinggi variabel $\mathrm{X}$ maka semakin rendah variabel $\mathrm{Y}$.

\section{DAFTAR PUSTAKA}


Al. Tridhonanto \& Beranda Agency. 2014. Mengembangkan Pola Asuh Demokratis.Jakarta: PT Gramedia.

Dasmo, Nurhayati, Marhento. 2013. Pengaruh Tingkat Pendidikan Dan Pola Asuh Orang Tua Terhadap Prestasi Belajar IPA. Jurnal Formatif No. 2 Vol 2: 132-139.

Djamarah, Saiful Bahri. 2014. Pola Komunikasi Orang Tua \& Anak Dalam Keluarga. Jakarta: Rineka Cipta.

Hamalik, Oemar. 2014. Kurikulum dan Pembelajaran. Jakarta: Bumi Aksara.

Halawa Aristina, 2017. Hubungan Pola Asuh Orang Tua Dengan Prestasi Belajar Anak Kelas $4 \mathrm{Sd}$.. Jurnal Stikes Williambooth. No. 1 Vol 6 Hal 1-8.

Istiyarini, 2013 "Pola Asuh Membentuk Karakter Anak", Jurnal Psikologi plus, Vol 2, No 06.

Karnangsyah Emi, 2017. Hubungan Pola Asuh Orangtua Dengan Hasil Belajar Siswa dan Implikasinya Terhadap Pelayanan Bimbingan dan Konseling. Jurnal Educatico, Vol. 3 No. 1 Hal 1-9.

Putri, Retpusa. 2013. Pengaruh Pola Asuh Orang Tua Terhadap Prestasi Belajar Ipa Siswa Kelas Vii Smp Nurul Islam Ngemplak Boyolali Tahun Ajaran 2011/2012. Jurnal Formatif No. 2, Vol. 17: 158-175.
Setiasih dwi Yuli, 2015. Hubungan Pola Asuh Orang Tua Dengan Prestasi Belajar Siswa Kelas V Sd Se-Gugus Wonokerto Turi Sleman. Jurnal Sosial Sains dan Pendidikan. No. Vol. 3 Hal 5-6.

Sugiyono. 2013. Metode Penelitian Pendidikan Pendekatan Kuantitatif, Kualitatif, dan R\&D. Bandung: Alfabeta.

Susanto Achmad. (2013). Teori Belajar dan Pembelajaran di Sekolah Dasar.Jakarta: Kencana.

Wahyudi Dwi Arif, Nurayati Faridha. 2015. Hubungan Pola Asuh Orang Tua Dengan Prestasi Belajar Pendidikan Jasmani Siswa Kelas VI SDN Kalipecabean Candi Sidoarjo. Jurnal Pendidikan Olahaga dan Kesehatan, Vol 03 No. 02 Hal 577-580.

Wydia, Sumilah. 2016. Pengaruh Pola Asuh Orangtu A Terhadap Prestasi Belajar Ips Melalui Motivasi Belajar (Studi Pada Siswa Kelas Iv, V, Vi Gugus 2 Kecamatan Ngantang Kabupaten Malang). Jurnal Kependidikan Dasar. Vol. 1 No. 5 Hal 865-873.

Widhiasih, I., Sumilah, Abbas, N. (2017).Pengaruh Pola Asuh Orang Tua Terhadap Hasil Belajar IPS. Jurnal Kreatif: Jurnal Kependidikan Dasar. Vol 7 No.2, Hal 189-199.

Widiantari, Suarjana. 2020. Hubungan Antara Pola Asuh Orang Tua Dengan Hasil Belajar Ipa Siswa Kelas V. Jurnal Mimbar Ilmu, Vol. 25 No. 2 Hal 232239. 